UDC 617.7-007.681:615.216.84:615.036.8

DOI: $10.15587 / 2313-8416.2016 .65160$

\title{
ANTIGLAUCOMA PHARMACOTHERAPY: ANALYSIS OF TREATMENT REGIMENS AND EFFICACY INDICATORS
}

\section{(C) O. Kryvoviaz}

\begin{abstract}
Метою роботи є оцінка призначених схем терапії первинної відкритокутової глаукоми з точки зору їх відповідності протоколу надання допомоги відповідній групі пацієнтів, а також оцінка ефективності терапї за критерієм ступеня зниження внутрішньоочного тиску.
\end{abstract}

Методи дослідження. Дослідження було проведено на основі даних амбулаторних карт пацієнтів 3 діагнозом "первинна відкритокутова глаукома". В досліджуваній групі пацієнтів було призначено 49 різних варіантів комбінацій препаратів, щзо включають в себе від одного до трьох протиглаукомних препаратів у формі очних крапель.

Результати дослідження. До складу найчастіше призначуваних восьми схем входили переважно препарати першої лінії фармакотерапї глаукоми. П'ять з восьми досліджуваних схем передбачали монотерапію, та тільки три схеми включали в себе по два лікарських препарати. Також було розраховано ступінь зниження ВОТ пацієнтів, які отримували вищезгадані схеми лікування, порівняно з початковими показниками ВОТ, зафіксованими при встановленні діагнозу. Встановлено, щяо найбільшу ефективність мають схеми терапї̈, ше містять арутимол 0,5\% або азопт в комбіначії з тафлотаном. Вивчення розподілу призначень схем протиглаукомних препаратів в залежності від стадії ПВКГ показало, щзо монотерапію отримували пацієнти з І стадією захворювання, а комбіновані схеми застосовувались, переважно, для лікування пачієнтів з ІІІ стадією ПВКГ.

Висновки. Результати проведеного аналізу дозволили встановити найбільш часто призначувані схеми протиглаукомної терапї, які є ефективними в досягненні ияільового ВОТ, щзо в подальшому будуть використані для фармакоекономічного аналізу.

Ключові слова: первинна відкритокутова глаукома, ефективність фармакотерапії, внутрішньоочний тиск, схеми лікування, протиглаукомні препарати.

The purpose of this paper is to assess regimens administered for treatment of primary open-angle glaucoma in terms of their compliance with the Protocol of medical care to appropriate group of patients, as well as assessment of the therapy efficacy by the criterion of a degree of intraocular pressure reduction.

Research methods. The study was conducted on the basis of data received from outpatients diagnosed "primary open-angle glaucoma". 49 different variants of medicine combinations, consisting of one to three antiglaucoma medicines in the pharmaceutical form of eye drops were prescribed to patients from the subject group.

Results of the study. The eight most commonly prescribed regimens consisted primarily of first-line medicines for glaucoma pharmacotherapy. Five of eight subject regimens consisted in monotherapy and only three regimens consisted of two medicines. Also, we calculated a degree of IOP decrease in patients received the above treatment regimens compared with baseline IOP indicators, established at diagnosis stage. It was found that the most effective regimens were the ones containing Arutimol $0.5 \%$, or Azopt in combination with Taflotan. The study of distribution of regimens containing antiglaucoma medicines, depending on the POAG stage, demonstrated that patients with a stage I disease were administered monotherapy, whilst combined regimens were used mainly for treatment of patients with stage III POAG.

Conclusion. The results of the analysis allowed us to determine the most commonly prescribed regimens of antiglaucoma therapy, effective in reaching the target IOP, which consequently would be used for pharmacoeconomic analysis

Keywords: primary open-angle glaucoma, the efficacy of pharmacotherapy, intraocular pressure, treatment regimens, antiglaucoma medicines

\section{Introduction}

Growing incidence and severity of the disease, high disability rates, as well as its significant impact on quality of life of patients make it necessary to address the issues of improvement of primary open-angle glaucoma pharmacotherapy (POAG) [1-3]. There are many regimens for treatment of this disease [4-7], however the problem of underlying rationale for choosing the most efficient method of pharmacotherapy based on results of comprehensive study is still actual.

Despite advances of pharmacology and medical science in treatment of glaucoma, pharmacotherapy of patients with this pathology often does not lead to the desired results and remains ineffective.

2. Formulation of the problem in general, the relevance of the topic and its connection with important scientific or practical issues

POAG is an urgent problem not only in the medical and social, but also in economic context, as it leads to significant financial expenses both at the level of an individual patient, and at the state level $[8,9]$. Development and improvement of antiglaucoma medicines lead to higher efficacy of treatment, but in most cases also re- 
sults in higher costs. Therefore, an important parameter is the data on effect of pharmacotherapy on the cost of living and life quality, as far as temporary incapacity, and disability even more so, are the causes of significant financial losses both for patient's family, and for the state budget [10-12].

\section{Analysis of recent research and publications} addressing the said problem, being the grounds for the author`s work

Availability of standardized, legally regulated criteria for evaluating the efficacy of various regimens for POAG pharmacotherapy is considered an essential tool and a criterion for selection of medicines from S01E group - antiglaucoma medicines and miotics for medical treatment of patients and prevention of disease progression.

That criterion of POAG is reaching a target intraocular pressure (IOP). The main principle involves reduction of initial pressure by 25-30\% compared to the one recorded in a patient at diagnosis stage $[5,7,10]$.

\section{Isolation of previously unsolved aspects of} general problem, being the subject of the article

Since glaucoma is a chronic pathology, in most cases the disease keeps progressing despite treatment. Therefore, the main objective of reducing IOP is to slow the rate of disease progression. A primary goal of treatment is to avoid the loss of vision by patient and his/her life-long disability, and to promote preservation and improvement of the life quality.

Therefore, one of the fundamental problems of pharmacotherapy is considered an individual approach to a patient and rational selection of medicines based on a maximum efficiency and safety, and optimal costs, affordable for POAG patients as a treatment spending.

\section{Formulation of goals (objectives) of the article}

The purpose of this article is to assess administered regimens for treatment of primary open-angle glaucoma in terms of their compliance with the Protocol of medical care to appropriate group of patients, as well as assessment of the therapy efficacy by the criterion of a degree of intraocular pressure reduction.

6. Presentation of main research material (methods and subjects) and substantiation of the results obtained

The study was conducted on the basis of data obtained from medical records of 534 outpatients residing in the Vinnytsia region, aged 37 to 92 years (mean age 71.45 years), which, as of May 2015, were at the dispensary with a diagnosis of "primary open-angle glaucoma" (Fig. 1).

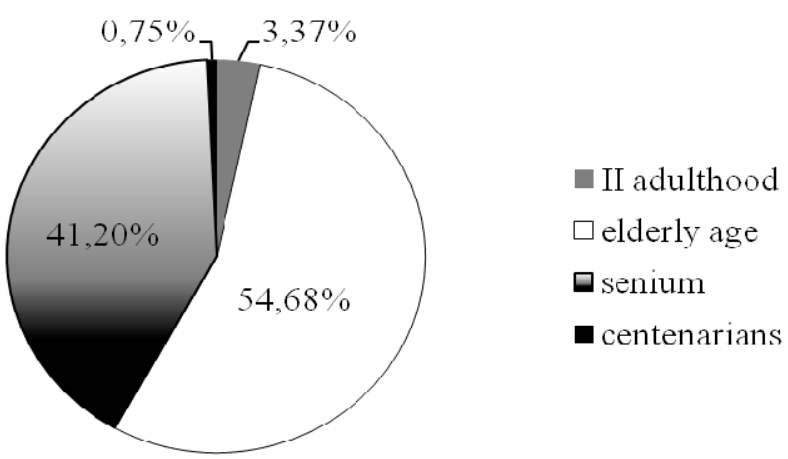

Fig. 1. Age characteristics of patients with POAG

A statistical analysis of the results was performed using "Statistica 10.0" software package and Microsoft Office Excel 2013.

In accordance with requirements of the regulation "Open primary glaucoma. Adapted clinical guidelines based on evidence" (2011), target intraocular pressure is considered a measure that is $25-30 \%$ below the initial value at which the diagnosis was established. This same value served as a criterion for evaluating the efficacy of administered pharmacotherapy.

In general, the studied group of patients was prescribed 49 different variants of medicines combinations consisting of one to three medicinal products in the form of eye drops (Fig. 2).

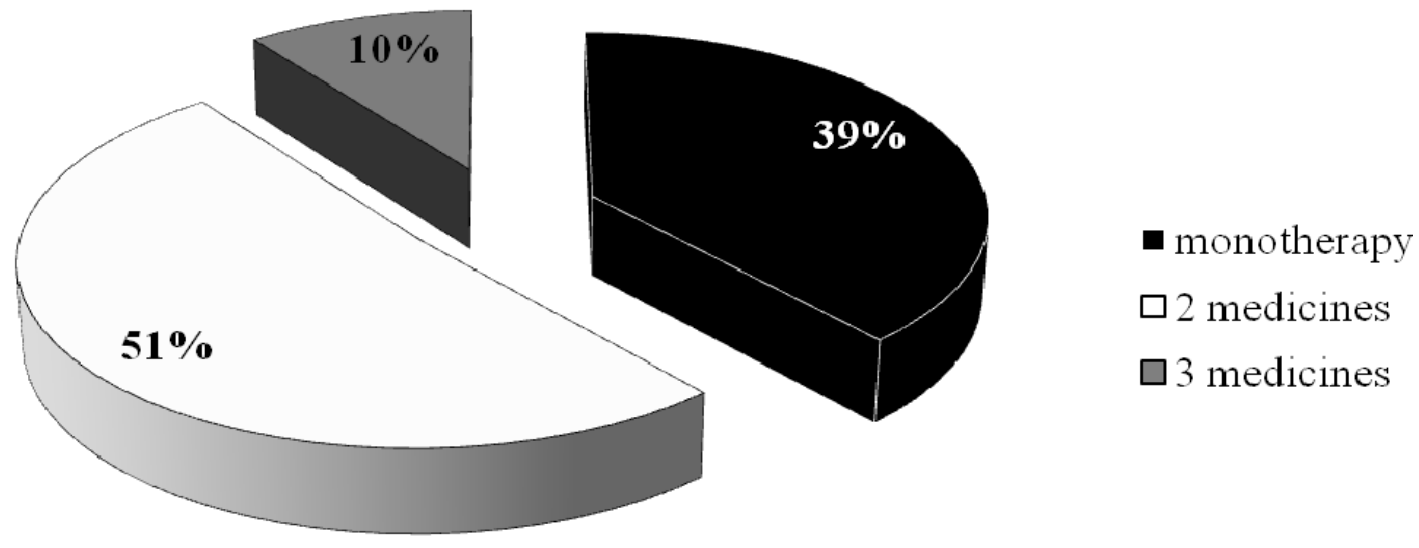

Fig. 2. Quantitative structure of antiglaucoma pharmacotherapy regimens

All regimens used in the treatment of POAG contained medicines included in the formulary list [12], rele- vant to the protocol of management of patients with glaucoma (Table 1) [5, 7]. 
Table 1

Incidence of administration of treatment regimens in patients with primary open-angle glaucoma

\begin{tabular}{|c|c|}
\hline $\begin{array}{c}\text { Composition of antiglaucoma } \\
\text { pharmacotherapy regimen }\end{array}$ & $\begin{array}{c}\text { Administration } \\
\text { incidence, } \%\end{array}$ \\
\hline Arutimol $0,5 \%$ & 13,48 \\
\hline Arutimol 0,5\%+Taflotan & 8,24 \\
\hline Arutimol 0,5\%+ Lanotan & 7,49 \\
\hline Lanotan & 7,49 \\
\hline Azopt & 5,99 \\
\hline Azopt+Taflotan & 4,87 \\
\hline Timolol 0,25\% & 4,49 \\
\hline Taflotan & 3,75 \\
\hline Fotil & 3,37 \\
\hline Lanotan + Azopt & 3,37 \\
\hline Arutimol $0,25 \%$ & 1,87 \\
\hline Arutimol 0,5\%+ Azopt & 1,87 \\
\hline Taflotan + Azarga & 1,87 \\
\hline Betoptic + Taflotan & 1,87 \\
\hline Lanotan + Azarga & 1,87 \\
\hline Arutimol $0,5 \%+$ Travatan & 1,87 \\
\hline Lanotan+ Oftan Timolol 0,5\% & 1,87 \\
\hline Azarga & 1,87 \\
\hline Oftan Timolol 0,5\% & 1,87 \\
\hline Ganfort & 1,50 \\
\hline Taflotan + Dorsamed & 1,50 \\
\hline Azopt + Travatan & 1,50 \\
\hline Travatan & 1,50 \\
\hline Duotrav & 1,50 \\
\hline Betoptic & 1,12 \\
\hline Pilocarpin + Timolol 0,5\% & 1,12 \\
\hline Pilocarpin + Arutimol 0,5\% & 1,12 \\
\hline Pilocarpin + Arutimol 0,25\% & 1,12 \\
\hline Arutimol 0,5\%+ Betoptic & 0,75 \\
\hline Azarga + Travatan & 0,75 \\
\hline Fotil forte & 0,37 \\
\hline Timolol 0,5\%+ Taflotan & 0,37 \\
\hline Oftan Timolol 0,5\%+ Ganfort & 0,37 \\
\hline Arutimol 0,5\%+ Taflotan + Alphagan P & 0,37 \\
\hline Taflotan + Oftan Timolol 0,5\% & 0,37 \\
\hline Pilocarpin + Azopt & 0,37 \\
\hline Pilocarpin & 0,37 \\
\hline Arutimol 0,5\% + Azopt + Taflotan & 0,37 \\
\hline $\begin{array}{c}\text { Pilocarpin + Arutimol } 0,5 \%+ \\
+ \text { Taflotan }\end{array}$ & 0,37 \\
\hline Lanotan + Arutimol 0,25\% & 0,37 \\
\hline Betoptic + Oftan Timolol 0,5\% & 0,37 \\
\hline Betoptic + Travatan & 0,37 \\
\hline Timolol 0,5\%+ Fotil forte & 0,37 \\
\hline Azopt + Azarga + Travatan & 0,37 \\
\hline Azopt + Oftan Timolol 0,5\% & 0,37 \\
\hline Fotil forte + Taflotan & 0,37 \\
\hline Azarga + Alphagan P + Travatan & 0,37 \\
\hline Alphagan $\mathrm{P}+$ Travatan & 0,37 \\
\hline Duotrav + Ocuril & 0,37 \\
\hline
\end{tabular}

Analysis of the data from Table 1 indicates that vast majority of treatment regimens have been prescribed in a few cases that made impossible to reliably assess their efficacy. Therefore, the eight most frequently prescribed medicines and combinations have been selected (Fig. 3) which has consequently become the subject of analysis against the above criteria.

The eight studied regimens consisted of mostly first-line medicines for glaucoma pharmacotherapy - the analogues of prostaglandins and beta-blockers. As one can see from the data in Fig. 3, five of the eight studied regimens of POAG pharmacotherapy consisted in monotherapy, and only three regimens consisted of two medicines from S01E pharmaceutical group - antiglaucoma medicines and miotics.

In the next phase of the study we calculated a degree of IOP decrease in patients receiving the above treatment regimens, compared with baseline IOP, registered at POAG diagnosis. It was found that the most effective regimens contained Arutimol $0.5 \%$, or Azopt or in combination with Taflotan $(40.04 \%$ and $39.09 \%$, respectively) (Table 2).

Table 2

Efficacy of antiglaucoma medicines

\begin{tabular}{|c|c|}
\hline $\begin{array}{c}\text { Composition of POAG pharma- } \\
\text { cotherapy regimen }\end{array}$ & $\begin{array}{c}\text { A degree of IOP } \\
\text { reduction } \\
\text { compared to } \\
\text { baseline, } \%\end{array}$ \\
\hline Azopt+Taflotan & $40,04 \pm 7,59$ \\
\hline Arutimol 0,5\%+Taflotan & $39,09 \pm 7,73$ \\
\hline Arutimol 0,5\%+ Lanotan & $37,55 \pm 6,8$ \\
\hline Azopt & $35,5 \pm 5,6$ \\
\hline Arutimol 0,5\% & $34,75 \pm 8,86$ \\
\hline Taflotan & $22,82 \pm 5,6$ \\
\hline Lanotan & $21,03 \pm 7,18$ \\
\hline Timolol 0,25\% & $17,68 \pm 6,98$ \\
\hline
\end{tabular}

The data presented in Table 2, suggests of lacking efficiency of monotherapy with Lanotan, Timolol $0.25 \%$ and Taflotan due to failure to achieve the target IOP in a studied group of patients with POAG.

In order to identify the special features of POAG pharmacotherapy, we analyzed the prescription of eight studied regimens, depending on the stage of the disease (Table 3) and the age of patients (Fig. 4).

The study of distribution of regimens prescription in patients with different stages of primary open-angle glaucoma showed that monotherapy was prescribed to patients with I (Taflotan, Lanotan, Timolol $0.25 \%$ ) and II (Azopt, Arutimol $0.5 \%$ ) stages of the disease. Combined scheme (Azopt + Taflotan, Arutimol $0.5 \%+$ + Taflotan, Arutimol $0.5 \%$ + Lanotan) were administered mainly for treatment of patients with stage III POAG. 


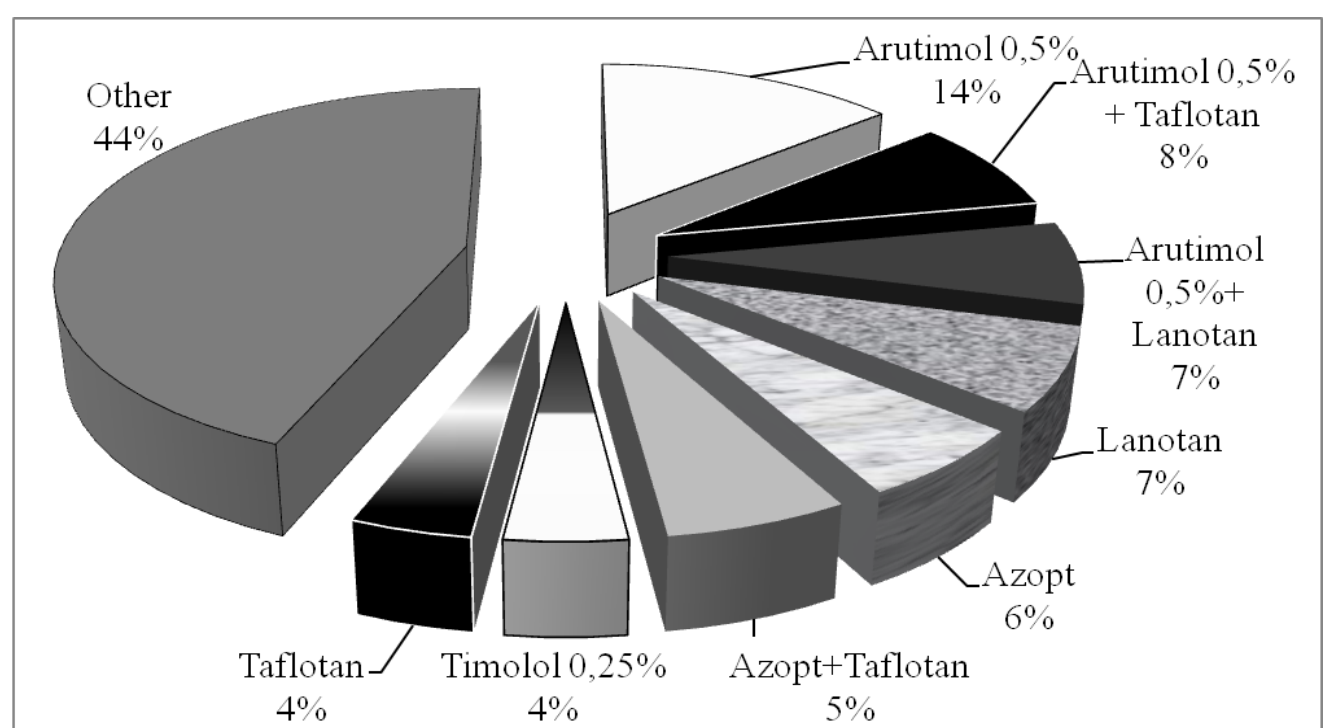

Fig. 3. Qualitative composition of the most commonly prescribed antiglaucoma pharmacotherapy regimens

Table 3

Structure of regimens prescription in patients with different stages of primary open-angle glaucoma

\begin{tabular}{|c|c|c|c|c|}
\hline \multirow{2}{*}{$\begin{array}{c}\text { Composition of POAG } \\
\text { pharmacotherapy regimen }\end{array}$} & \multicolumn{4}{|c|}{ Administration incidence by patients with different stages of } \\
\cline { 2 - 4 } & I & II & III & IV \\
\hline Azopt+Taflotan & 0 & 38,9 & 61,1 & 0 \\
\hline Arutimol 0,5\%+Taflotan & 22,8 & 61,3 & 15,9 & 0 \\
\hline Arutimol 0,5\%+ Lanotan & 30,0 & 15,0 & 55,0 & 0 \\
\hline Azopt & 21,9 & 40,6 & 34,4 & 3,1 \\
\hline Arutimol 0,5 \% & 30,5 & 34,7 & 27,8 & 7,0 \\
\hline Taflotan & 55,0 & 25,0 & 15,0 & 5,0 \\
\hline Lanotan & 62,5 & 27,5 & 10,0 & 0 \\
\hline Timolol 0,25\% & 75,0 & 25,0 & 0 & 0 \\
\hline
\end{tabular}

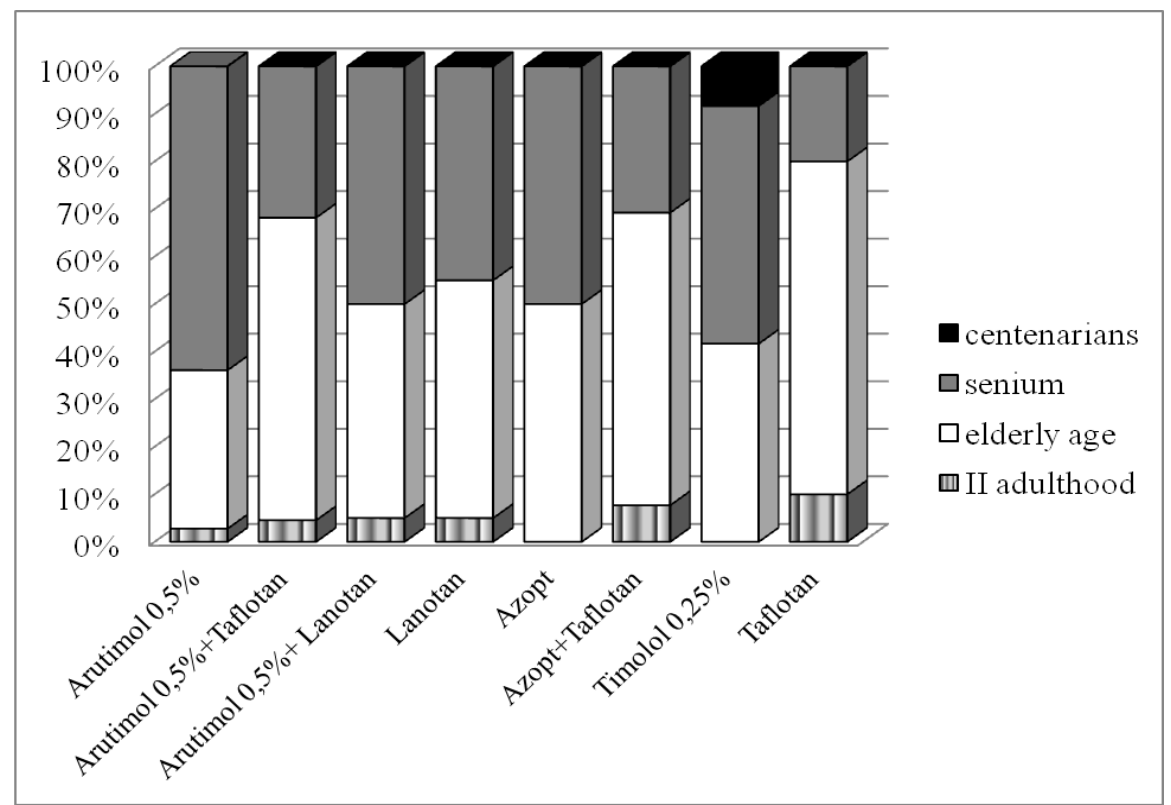

Fig. 4. Structure of distribution of regimens prescription in patients from different age groups

The results for age classification of patients who received different POAG treatment regimens show a preferential administration of mono- and combined regimens including Taflotan in elderly patients with glaucoma. At the same time, patients over 75 were more often prescribed medicines from S01E D01 group - Beta-blockers (Arutimol $0.5 \%$ and Timolol $0.25 \%$ ). 


\section{Findings from the research and prospects of} further development of this topic

The results of the analysis have made it possible to determine the most commonly prescribed regimens of antiglaucoma therapy being effective in achieving the target IOP. The received data will consequently be used for pharmacoeconomic analysis by "cost-effectiveness" method.

\section{References}

1. Global Initiative for the Elimination of Avoidable Blindness: action plan 2006-2011 [Text]. - World Health Organization, 2007. - Available at: http://www.who.int/ blindness/Vision2020_report.pdf

2. Volkov, V. V. Glaukoma otkrytougol'naja [Text] / V. V. Volkov. - M.: MIA, 2008. - 352 p.

3. Pasjechnikova, N. V. Social'ni aspekty poperedzhennja slipoty, organizacija medychnoi' dopomogy ta reabilitacija hvoryh na glaukomu [Text] / N. V. Pasjechnikova, S. O. Rykov, O. P. Vitovs'ka et. al. - K.: TOV "Doktor-Media”, 2009. - 172 p. 4. Duglas, Dzh. R. Glaukoma [Text] / Dzh. R. Duglas. - M.: GJeOTAR-Media, 2010. - 472 p.

5. Pro zatverdzhennja ta vprovadzhennja medykotehnologichnyh dokumentiv zi standartyzacii' medychnoi' dopomogy na zasadah dokazovoi' medycyny [Text]. - Nakaz MOZ Ukrai'ny vid 23.11.2011; № 816, 2011. - Available at: http://www.moz.gov.ua/ua/portal/dn_20111123_816.html

6. Nesterov, A. P. Glaukoma [Text] / A. P. Nesterov. M.: Medicinskoe informacionnoe agentstvo, 2008. -360 p.

7. Rykov, S. O. Organizacija oftal'mologichnoi' dopomogy. Normatyvno-pravove zabezpechennja: dovidnyk likarja "Oftal'molog" [Text]: navch.-metod. pos. / S. O. Rykov, G. V. Shpak, N. S. Lavryk et. al; S. O. Rykov (Ed.); Nacional'na medychna akademija pisljadyplomnoi' osvity imeni P. L. Shupyka, Nacional'nyj medychnyj universytet imeni O. O. Bogomol'cja. - K.: Biblioteka "Zdorov'ja Ukrai'ny", 2013. - 498 p.

8. Damji, K. F. Shields' Textbook of Glaucoma [Text] / K. F. Damji, S. Freedman, S. E. Moroi. - 6-th ed. - Lippincott Williams \& Wilkins, 2010. - 656 p.

9. Terminology and guidelines for glaucoma [Text]. European Glaucoma Society. - Savona: Publicomm srl., 2008. - 184 p.

10. Vorob'ev, P. A. Kliniko-jekonomicheskij analiz [Text] / P. A. Vorob'ev, M. V. Avksent'eva, A. S. Jur'ev et. al. Moscow: Izdatel'stvo «N'judiamed», 2004. - 404 p.

11. Devine, E. B. Strategies to Optimize Medication Use in the Physician Group Practice: The Role of the Clinical Pharmacist [Text] / E. B. Devine, S. Hoang, A. W. Fisk, J. L. Wilson-Norton,
N. M. Lawless, C. Louie // Journal of the American Pharmacists Association. - 2009. - Vol. 49, Issue 2. - P. 181-191. doi: 10.1331/japha.2009.08009

12. Pro zatverdzhennja s'omogo vypusku Derzhavnogo formuljara likars'kyh zasobiv ta zabezpechennja jogo dostupnosti [Text]. - Nakaz MOZ Ukrai'ny vid 30.03.2015; № 183, 2015. - Available at: http://www.moz.gov.ua/ua/portal/ dn_20150330_0183.html

\section{References}

1. Global Initiative for the Elimination of Avoidable Blindness: action plan 2006-2011 (2007). World Health Organization. Available at: http://www.who.int/blindness/Vision2020_report.pdf

2. Volkov, V. V. (2008). Glaukoma otkrytougol'naja. Moscow: MIA, 352

3. Pasjechnikova, N. V., Rykov, S. O., Vitovs'ka, O. P. et. al (2009). Social'ni aspekty poperedzhennja slipoty, organizacija medychnoi' dopomogy ta reabilitacija hvoryh na glaukomu. Kyiv: TOV "Doktor-Media”, 172.

4. Duglas, Dzh. R. (2010). Glaukoma. Moscow: GJeOTAR-Media, 472.

5. Pro zatverdzhennja ta vprovadzhennja medyko-tehnologichnyh dokumentiv zi standartyzacii' medychnoi' dopomogy na zasadah dokazovoi' medycyny (2011). Nakaz MOZ Ukrai'ny vid 23.11.2011; № 816. Available at: http://www.moz.gov.ua/ ua/portal/dn_20111123_816.html

6. Nesterov, A. P. (2008). Glaukoma. Moscow: Medicinskoe informacionnoe agentstvo, 360.

7. Rykov, S. O., Shpak, G. V., Lavryk, N. S. et. al; Rykov, S. O. (Ed.) (2013). Organizacija oftal'mologichnoi' dopomogy. Normatyvno-pravove zabezpechennja: dovidnyk likarja "Oftal'molog". Kyiv: Biblioteka "Zdorov'ja Ukrai'ny", 498.

8. Damji, K. F., Freedman, S., Moroi, S. E. (2010). Shields' Textbook of Glaucoma. Lippincott Williams \& Wilkins, 656.

9. Terminology and guidelines for glaucoma (2008). European Glaucoma Society. Savona: Publicomm srl., 184.

10. Vorob'ev, P. A., Avksent'eva, M. V., Jur'ev, A. S. et. al (2004). Kliniko-jekonomicheskij analiz. Moscow: Izdatel'stvo «N'judiamed», 404.

11. Devine, E. B., Hoang, S., Fisk, A. W., Wilson-Norton, J. L., Lawless, N. M., Louie, C. (2009). Strategies to optimize medication use in the physician group practice: The role of the clinical pharmacist. Journal of the American Pharmacists Association, 49 (2), 181-191. doi: 10.1331/japha.2009.08009

12. Pro zatverdzhennja s'omogo vypusku Derzhavnogo formuljara likars'kyh zasobiv ta zabezpechennja jogo dostupnosti (2015). Nakaz MOZ Ukrai'ny vid 30.03.2015; № 183. Available at: http://www.moz.gov.ua/ua/portal/dn_20150330_0183.html

Рекомендовано до публікаиії д-р мед. наук, професор Германюк Т. А. Дата надходження рукопису 18.02.2016

Kryvoviaz Olena, Candidate of Pharmaceutical Sciences, Associate Professor, The Head of Department, Pharmacy Department, Vinnytsia National Pyrohov Memorial Medical University, Pyrohov str., 56, Vinnytsia, Ukraine, 21018

E-mail: SK16124@rambler.ru 